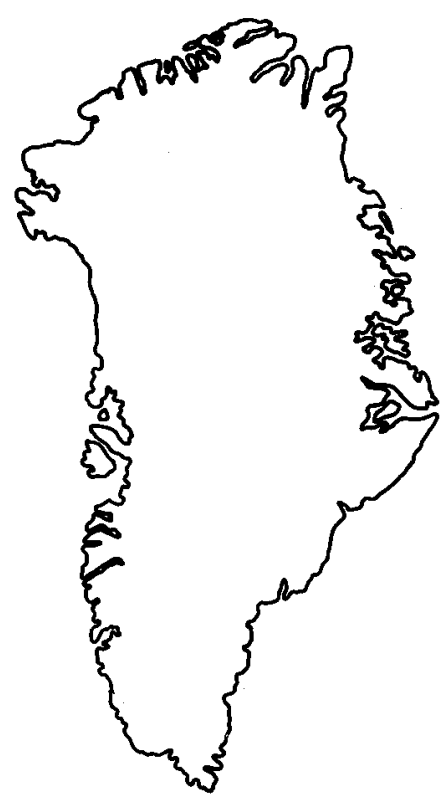

\title{
Ordovician conodonts from the Precambrian Shield of southern West Greenland
}

\author{
Svend Stouge and John S. Peel
}

Limestone blocks in a fault zone breccia in the Precambrian Shield near Sukkertoppen, West Greenland, have yielded a small conodont fauna of late Middle Ordovician - Late Ordovician age, including Plectodina furcata and Panderodus gracilis.

S.S. Department of Mines \& Energy, Mineral Development Division, P. O. Box 4750, St. John's, Newfoundland A1C 5T7, Canada.

J.S.P. Grønlands Geologiske Undersøgelse, Øster Voldgade 10, $D K-1350$ København K, Danmark.

The occurrence of fossiliferous Lower Palaeozoic rocks in the Archaean terrain of West Greenland, near Sukkertoppen (fig. 1), was documented by Poulsen (1966). The locality, unofficially known as 'Fossilik', was more fully described by Poulsen (1967a, b) who noted that blocks of various sediment types are included within a breccia developed in a fault zone trending about $60^{\circ}$. Poorly preserved fossils, including cyclostome bryozoans, orthid brachiopods, the pygidium of an asaphid trilobite, Climacograptus sp., and the conodonts Paltodus?, (Panderodus?) and Belodus?, were considered by Poulsen to suggest a Middle Ordovician to Early Silurian age.

'Fossilik' is of considerable importance in attempts to assess the former distribution of Ordovician, and possibly other Lower Paleozoic strata in the Precambrian Shield areas of Greenland and neighbouring Arctic Canada. The locality lies more than $1000 \mathrm{~km}$ to the East of the nearest exposures of Ordovician on land, around Foxe Basin in Arctic Canada, although Ordovician strata have been encountered in off-shore boreholes, south-east of Baffin Island (McLean et al., 1977). Still greater distances separate 'Fossilik' from sediments of equivalent age in western North Greenland and East Greenland (fig. 1).

Both the sedimentary character and faunal composition of the limestones from 'Fossilik' indicate derivation from a shelf deposited sequence. The material probably represents the remains of a blanket of shallow water limestones deposited on the Archaean basement during one of the transgressive episodes characteristic of the North American craton during the Middle and Upper Ordovician (Fåhræus, 1976; Le Fèvre et al., 1976).

The conodonts discussed below were recovered from samples collected at 'Fossilik' by Dr. B.F. Windley in 1967. The fauna is more numerous and diverse than that reported by Poulsen 


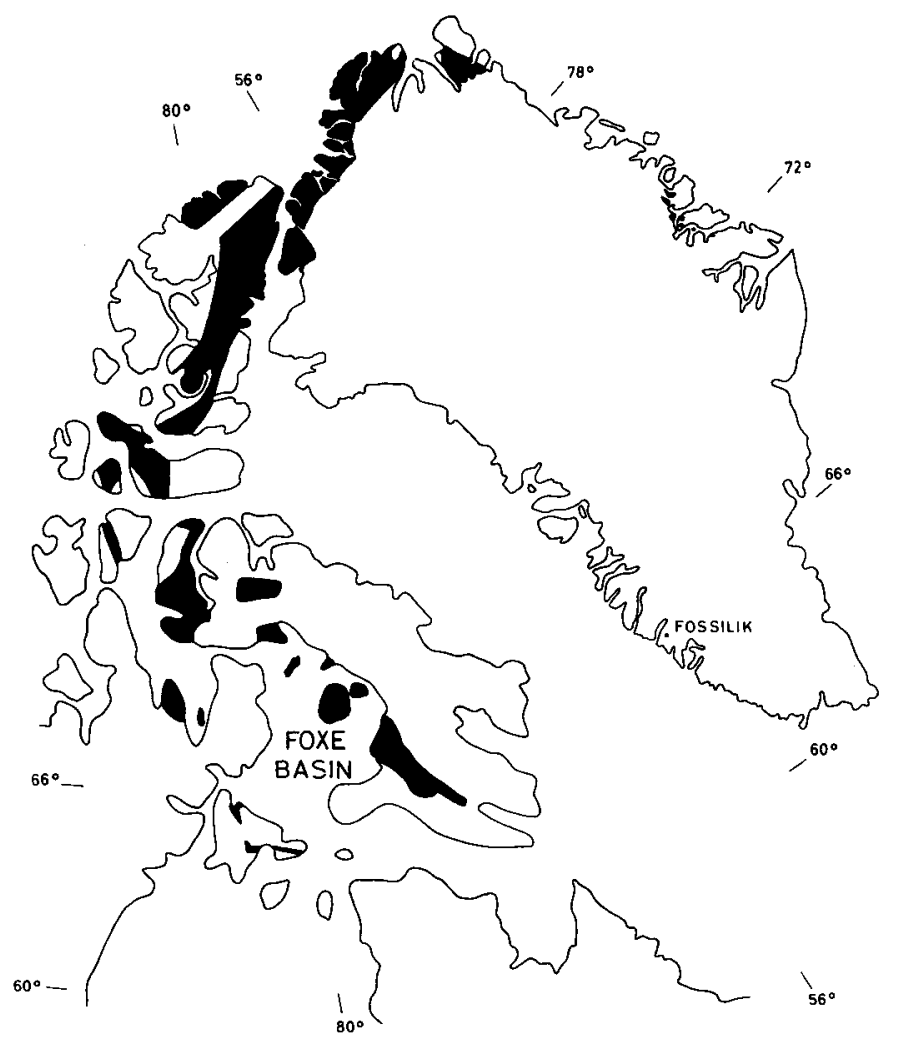

Fig. 1. Areas of outcrop of Ordovician strata, including some undifferentiated Cambrian and Silurian, in Greenland and adjacent Arctic Canada.

(1967a) although still rather indifferently preserved and sparse. A general late Middle to Late Ordovician age is indicated but more precise determination is not possible.

The locality at 'Fossilik' was revisited by GGU geologists during 1977 and additional collections made for processing in Copenhagen. It is hoped that the results of this future processing will serve to more closely define the age range of strata included within the fault zone.

\section{The conodont fauna}

A fairly diverse donodont fauna was recovered from GGU 92780 but only a few elements were obtained from the other two samples processed (Table 1). Panderodus gracilis (Branson \& Mehl) elements are numerically dominant, but Plectodina furcata (Hinde) and the form genus ?Scandodus Lindström are fairly well represented. Only one specimen of the form genus Drepanodus Pander was found. Broken elements, representing fragments of indeterminate conodonts occur in all samples. All specimens are yellow to amber in colour with clearly visible white matter, when present. A number of scolecodonts were obtained from GGU 92773.

Panderodus gracilis (fig. 2A) is identical with descriptions given by Bergström \& Sweet (1966). Plectodina furcata (fig. 2C-F) is present in the form of an almost complete apparatus, consisting of cordylodiforms, trichonodelliforms, dichognathodiforms, prioniodiforms, cyrtoniodiforms, and zygognathiforms - only ozarkodiforms were not recovered. Drepanodus sp. $s . f$. 
Table 1. Additional conodonts from 'Fossilik'

\begin{tabular}{|c|c|c|c|}
\hline & $\begin{array}{c}\text { GGU } \\
92773\end{array}$ & 92780 & 92786 \\
\hline Panderodus gracilis (Branson \& Mehl) & + & + & \\
\hline Plectodina furcata (Hinde) & & + & \\
\hline Drepanodus cf. D. arcuatus Pander & & + & \\
\hline Drepanoistodus sp. Lindström & & + & \\
\hline Drepanodus sp. s.f. Pander & + & & \\
\hline ? Scandodus sp. s.f. Lindström & & + & \\
\hline fragments & + & + & + \\
\hline Scolecodonts & + & & \\
\hline
\end{tabular}

The names are those of multielement taxa, except where indicated $(s . f .=$ sensu formae).

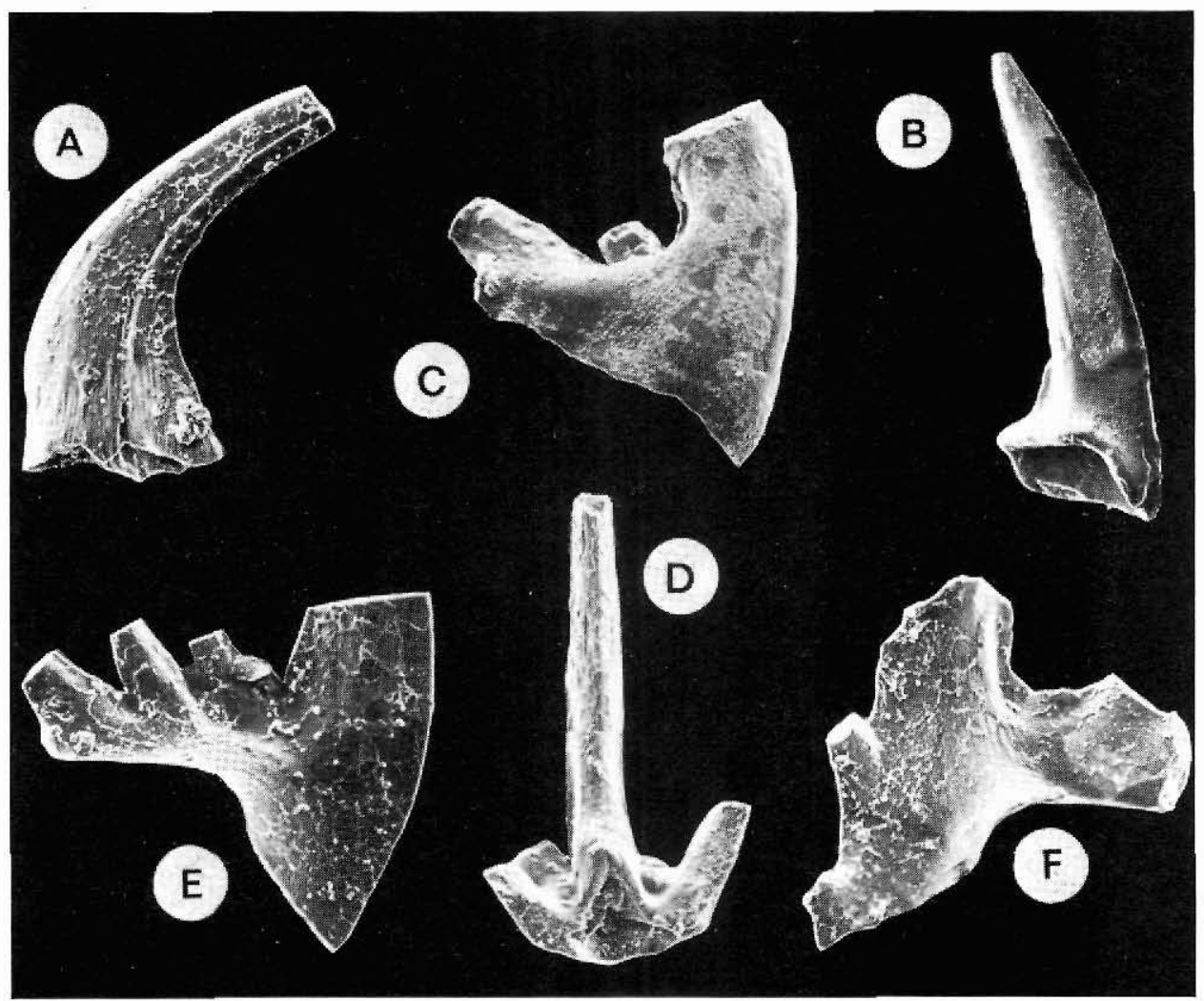

Fig. 2. Ordovician conodonts from 'Fossilik'. All specimens from GGU sample 92780; magnifications approximate. A, Panderodus gracilis (Branson \& Mehl), MGUH 14263, $\times 100$. B, ?Scandodus sp. s.f. Lindström, MGUH 14264, × 50. C-F. Plectodina furcata (Hinde); C, cordylodiform element. MGUH 14265, $\times 100 ; \mathrm{D}$, trichonodelliform element, MGUH 14266, $\times 120 ; \mathrm{E}$, cyrtoniodiform element, MGUH $14267, \times 150 ;$ prioniodiform element, MGUH 14268, $\times 130$. 
Pander cannot be assigned to any known species. It might be part of a multielement species but a closer statement of its affinities is not currently possible. ?Scandodus sp. s.f. Lindström (fig. 2B) consists of paired asymmetrical scandodiform elements. The material investigated here seems to indicate an apparatus with a single element type. All elements are hyaline.

The fauna belongs to the Midcontinent Province which is considered to be restricted to warm, shallow water environments on the craton of North America (Bergström, 1973; Barnes et al., 1973; Barnes \& Fåhræus, 1975; Bergström, 1977).

From a biostratigraphical viewpoint, the faunal elements are all long ranging, conservative species in terms of known time ranges. Panderodus gracilis is known from the Middle and Late Ordovician. Plectodina furcata is found in Faunas $9-12$ of Sweet et al. (1971), i.e. late Middle Ordovician (mid-Kirkfieldian) and Late Ordovician. It is not recorded prior to Fauna 9 or beyond the end of the Ordovician.

In terms of Balto-Scandinavian conodont zonation, Plectodina furcata is a contemporary of Amorphognathus tvaerensis Bergström and Amorphognathus ordovicicus Branson \& Mehl, which range from the Caradoc through the Ashgill.

The ages of GGU 92773 and GGU 92786 cannot be stated with any certainty on the available fossil evidence, but an age close to that of GGU 92780 is favoured. Thus it can be concluded that the three processed fossiliferous blocks from 'Fossilik' were derived from a late Middle to Late Ordovician unit. The age assignment is in accord with that suggested by Poulsen (1967) for other samples with macrofossils, although the processed samples give no indication of the possible Early Silurian age suggested by Poulsen.

Contemporaneous faunas of similar composition have been recorded in the lower part of the Thumb Mountain Formation on Bathurst Island, Arctic Canada (Barnes, 1974), and Hudson Bay (Le Fèvre et al., 1976). Sweet et al. (1971) have found similar faunal associations from sections in several different areas on the North American craton.

Acknowledgement. We are grateful to Dr. B.F. Windley (Leicester University) for supplying the samples from 'Fossilik'. Prof. S.M. Bergström (Ohio) and Prof. V. Poulsen (Copenhagen) offered useful criticism.

\section{References}

Barnes, C.R. 1974: Ordovician conodont biostratigraphy of the Canadian Arctic. In Aitken, J.D. \& Glass, D.J. (edit.) Symposium on Geology of the Canadian Arctic, 221-240. Geol. Assoc. Canada - Can. Soc. Petrol. Geol. Special Volume. Calgary.

Barnes, C.R. \& Fåhræus, L.E. 1975: Provinces, communities, and the proposed nektobenthic habit of Ordovician conodontophorids. Lethaia 8, 133-149.

Barnes, C.R., Rexroad, C.B. \& Miller, J.F. 1973: Lower Paleozoic conodont provincialism. In Rhodes, F.H.T. (edit.) Conodont Paleozoology. Geol. Soc. Amer. Spec. Pap. 141, 156-190.

Bergström, S.M. 1973: Ordovician conodonts. In Hallam, A. (edit.) Atlas of palaeobiogeography, 47-58. Amsterdam: Elsevier.

Bergström, S.M. 1977: Early Paleozoic conodont biostratigraphy in the Atlantic Borderlands. In Swain, F.M. (edit.) Stratigraphic micropaleontology of Atlantic basin and borderlands, 85-110. Developments in Palaeontology and Stratigraphy 6. Amsterdam: Elsevier.

Bergström, S.M. \& Sweet, W.C. 1966: Conodonts from the Lexington Limestone (Middle Ordovician) of Kentucky and its lateral equivalents in Ohio and Indiana. Bull. Am. Paleont. 50, 229, 271-441. 
Fåhræus, L.E. 1976: Conodontophorid ecology and evolution related to global tectonics. In Barnes, C.R. (edit.) Conodont Paleoecology. Geol. Assoc. Canada Spec. Pap. 15, 11-26.

Le Fèvre, J., Barnes, C.R. \& Tixier, M. 1976: Paleoecology of Late Ordovician and Early Silurian conodontophorids, Hudson Bay Basin. In Barnes, C.R. (edit.) Conodont Paleoecology. Geol. Assoc. Canada Spec. Pap. 15, 69-86.

McLean, B., Jansa, L.F., Falconer, R.K.H. \& Srivastava, S.P. 1977: Ordovician strata on the southeastern Baffin Island shelf revealed by shallow drilling. Can. J. Earth Sci. 14, 1925-1939.

Poulsen, V. 1966: An occurrence of Lower Palaeozoic rocks within the Precambrian terrain near Sukkertoppen. Rapp. Gronlands geol. Unders. 11, 26 only.

Poulsen, V. 1967a: Grønlands geologi: Palaozoikum. Københavns Universitets fond til tilvejebringelse af læremidler, 99 pp.

Poulsen, V. 1967b: Ordovician at Sukkertoppen. Meddr Dansk geol. Foren. 17, 146 only.

Sweet, W.C., Ethington, R.C. \& Barnes, C.R. 1971: North American Middle and Upper Ordovician conodont faunas. In Sweet, W.C. \& Bergström, S.M. (edit.) Symposium on Conodont Biostratigraphy. Geol. Soc. Amer. Mem. 127, 163-193. 